University of Windsor

Scholarship at UWindsor

\title{
$5-2008$
}

\section{Benefits of a supportive development climate for older workers}

Francine K. Schlosser

Odette School of Business, University of Windsor

Marjorie Armstrong-Stassen

Follow this and additional works at: https://scholar.uwindsor.ca/odettepub

Part of the Business Commons

\section{Recommended Citation}

Schlosser, Francine K. and Armstrong-Stassen, Marjorie. (2008). Benefits of a supportive development climate for older workers. Journal of Managerial Psychology, 23 (4), 419-437.

https://scholar.uwindsor.ca/odettepub/118

This Article is brought to you for free and open access by the Odette School of Business at Scholarship at UWindsor. It has been accepted for inclusion in Odette School of Business Publications by an authorized administrator of Scholarship at UWindsor. For more information, please contact scholarship@uwindsor.ca. 
Benefits of a Supportive Development Climate for Older Workers

Marjorie Armstrong-Stassen

Odette School of Business

University of Windsor

410 Sunset Avenue

Windsor, Ontario N9B 3P4 Canada

Tel: (519) 253-3000 ext. 3106

Fax: (519) 973-7073

e-mail: $\underline{\text { mas@ } @ \text { uwindsor.ca }}$

Francine Schlosser

Odette School of Business

University of Windsor

401 Sunset Avenue

Windsor, Ontario N9B 3P4 Canada

Tel: (519) 253-3000 ext. 3107

Fax: (519) 973-7073

e-mail: fschloss@uwindsor.ca

CITATION : Armstrong-Stassen, $M$ and Schlosser, FK, Benefits of a Supportive Development Climate for Older Workers, Journal of Managerial Psychology: Special Issue on Work and Well Being of Older Workers, 23(4), 419-437, 2008.

This study was supported by a grant from the Social Sciences and Humanities Research Council of Canada. 


\begin{abstract}
Purpose: This study tested a model of the relationships among older workers' propensity to engage in development activities (development orientation), their perceptions of the development opportunities associated with their job (job development climate), their commitment to their organization, and their intention to remain with their organization.

Methodology/Approach: Separate questionnaires were completed by 395 individuals aged 50 to 70 who were in their career job and 195 individuals aged 50 to 70 who were employed in a bridge job. Both questionnaires included measures of development orientation, job development climate, affective commitment and intention to remain as well as individual characteristics and organizational characteristics.
\end{abstract}

Findings: The findings supported the proposed model in that development orientation was positively related to job development climate which, in turn, was positively related to affective commitment and affective commitment was positively related to intention to remain with the organization. There were both similarities and differences in the patterns of relationships for career-job and bridge-job respondents.

Research limitations/implications: The question of causality cannot be determined because of the cross-sectional research design.

Practical implications: To create a supportive development climate and retain older workers, employers need to foster older workers' development orientation and ensure that their work assignments provide opportunities to learn new knowledge and skills.

Orginality/value of paper: There is little empirical research addressing issues related to the development and retention of older workers. No previous studies have investigated both development orientation and job development climate in the context of older workers. 
Keywords: older workers; training and development; development climate; development orientation; work centrality

Paper type: Research paper 


\section{Benefits of a Supportive Development Climate for Older Workers}

Although population aging is more advanced in Europe, Canada will be particularly affected by this phenomenon because of the relatively large size of its baby boom generation and its very low birth rate (Statistics Canada, 2003). According to Ibbott, Kerr, and Beaujot (2006), the rate of change in Canada is currently as rapid as that of European countries and will become more rapid than that of Europe once the larger baby boom generation cohorts move into retirement ages. Warnings of impending labour and skill shortages have been made along with calls for employers to implement policies and practices targeting the recruitment and retention of older workers, but few Canadian employers have developed a strategic response to the aging workforce (The Conference Board of Canada, 2005). Older workers with obsolete skills are the most likely to leave the labour force, either voluntarily or involuntarily (Auer \& Fortuny, 2000; Maurer, 2001). The Forum of Labour Market Ministers (2002) concluded that the most effective means of preventing the premature withdrawal of older workers from the labour force is lifelong learning and urged organizations to promote continuous learning among older workers.

The purpose of the present study was to develop and test a model of the relationships among older workers' propensity to engage in development activities (development orientation), their perceptions that their job provides them with development opportunities (job development climate), their attachment to their organization (affective commitment), and their intention to remain with their organization. Fuller and Unwin (2005) argued it is important to distinguish between the extent to which organizations provide development opportunities and encourage development activities and the extent to which individuals elect to engage in these opportunities. Thus, the present study examined both the extent to which older employees are willing to engage 
in development activities and the extent to which they perceive their job provides them with development opportunities.

Consistent with Greller (2006), we defined older workers as those who were 50 to 70 years of age. The present study differentiated between those older workers who remained employed in their long-term career job and those older workers who were employed in a bridge job. In this study, bridge employment refers to employment between leaving one's long-term career job and permanently exiting the workforce. It includes both partial retirement (the person has not officially retired from the workforce but has left his or her career job) and reverse retirement (the person retired from the workforce but has since re-entered the workforce). The duration of bridge employment can be fairly lengthy, especially for those older workers departing from their career jobs prior to age 60 (Ruhm, 1990). A main objective of the present study was to determine if the conceptual model we developed would be supported for these two groups of older workers.

\section{Conceptual Model}

The conceptual model is presented in Figure 1. Work centrality plays a prominent role in the theoretical framework, being related to development orientation, perceived job development climate, affective commitment, and intention to remain with the organization. Other individualrelated factors are expected to contribute to the formation of older workers' development orientation whereas organizational and job-related factors as well as development orientation shape older workers' perceptions of their job development climate. The proposed set of relationships between job development climate, affective commitment, and intention to remain with the organization are consistent with a social exchange framework (Blau, 1964) and the norm of reciprocity (Gouldner, 1960). Organizational actions, such as providing a supportive job 
development climate, are interpreted by employees as symbolic of their organization's commitment to them. According to the norm of reciprocity, perceptions of a supportive job development climate would create an obligation on the part of employees to repay the organization for its commitment to them. One way to do this is through their own commitment to the organization and continued participation in the organization (Allen, Shore \& Griffeth, 2003).

take in Figure 1

Work centrality refers to the overall importance of work in a person's life and represents a fairly stable set of beliefs (Paullay, Alliger \& Stone-Romero, 1994). Mannheim and Dubin (1986) found people with high work centrality were more likely to engage in job-specific vocational training than people with low work centrality. Mannheim, Baruch and Tal (1997) argued that people with high work centrality should have high career salience and therefore will invest effort into promoting future work opportunities. Therefore, older workers who view work as an important aspect of their life should exhibit a stronger desire to participate in development activities and to be more interested in and concerned about the development opportunities their job is providing. They are also more likely to be committed to their organization and to remain with the organization (Soon \& Tin, 1997).

Hypothesis 1: Work centrality is significantly positively related to development orientation, job development climate, affective commitment, and intention to remain in the organization.

We expected that older workers employed full time would have greater investment in their job and would therefore be more likely to participate in development activities than those 
working part time. Older workers who are working because they cannot afford to retire should be more concerned about retaining their job than older workers who are financially able to leave the workforce and would be more likely to engage in development activities to keep their skills and knowledge updated. Many bridge jobs are not located in the same industry or occupation as a person's career employment (Doeringer, 1990; Ruhm, 1990). Ruhm reported that less than half of people in bridge jobs remain in either their career industry or occupation. We speculated that older workers who spent time out of the workforce may be more likely to be in a different industry or occupation than those who went directly from their career job to a bridge job. If this is the case, we would expect those who spent time out of the workforce to be more likely to engage in development activities because they not only need to update their skills after being out of the workforce for some period of time but also their bridge job is more likely to require a different set of skills and knowledge than their career job.

Hypothesis 2a: Older workers in full-time jobs are significantly more likely to engage in development activities than those in part-time jobs.

Hypothesis 2b: Older workers who financially need to work are significantly more likely to engage in development activities than those who do not financially need to work. Hypothesis 2c: Bridge-job respondents who re-entered the workforce are significantly more likely to engage in development activities than those who went directly from their career job to their bridge job.

There is some evidence that employers in the public sector are more proactively addressing the issue of an aging workforce than employers in the private sector (Taylor \& Urwin, 2001). Some researchers (Leavitt, 1996; O’Reilly \& Caro, 1994) have speculated that union rules and policies limit the ability of organizations to implement practices and policies 
specifically designed to accommodate older workers. Labour unions have also promoted the use of early retirement incentives and have put pressure on older workers to retire early in order to preserve the jobs of younger workers (McNair, Flynn, Owen, Humphreys \& Woodfield, 2004). Many bridge jobs tend to be of lower status than a person's career job and to offer few development opportunities (Doeringer, 1990; Ruhm, 1990). Feldman and Kim (2000) reported that one of the negative attributes of bridge employment is underutilization associated with the quality of work assignments given to bridge employees.

Hypothesis 3a: Older workers employed in the public sector are significantly more likely to have development opportunities associated with their job than those who are employed in private-sector organizations.

Hypothesis 3b: Older workers who are represented by a union are significantly less likely to have development opportunities associated with their job than those who are not represented by a union.

Hypothesis 3c: Bridge-job respondents who perceive that they are overqualified for their bridge job are significantly less likely to have development opportunities associated with their job than those who do not feel underemployed in their bridge job.

According to Maurer (2002), employees who are oriented toward learning and development feel favourably toward learning experiences and are continuously and persistently involved in such experiences in the pursuit of their own development. Fugate, Kinicki and Ashforth (2004) argued that an orientation to actively pursue development activities represents a form of work-specific proactive adaptability. Seibert, Crant and Kraimer (1999) maintained that proactive individuals may be more likely to pursue opportunities for self-improvement such as acquiring further education or skills than less proactive people. We argue that not only will these 
individuals pursue development opportunities but they will also be more proactive in ensuring that their job provides them with development opportunities.

Hypothesis 4: Development orientation is significantly positively related to job development climate.

Job development climate reflects the degree to which jobs are designed to promote continuous learning and provide flexibility for acquiring new knowledge and skills (Tracey \& Tews, 2005, p. 358). Kozlowski and Hults (1987) proposed that development climate perceptions form the basis for employees' responses such as commitment to their organization. A supportive development climate has been shown to be positively related to organizational commitment (Kozlowski \& Hults, 1987). In fact, in a study of HR practices and affective commitment, Meyer and Smith (2000) found that evaluations of career development practices, including opportunities for personal development, were the best predictors of affective commitment.

Hypothesis 5: There is a significant positive relationship between job development climate and affective commitment.

Affective commitment has consistently been found to be significantly negatively related to turnover intention and positively related to intention to remain (Meyer, 1997). We expected that this relationship may even be stronger for older workers because affective commitment has been found to increase with age (Meyer, Allen \& Smith, 1993).

Hypothesis 6: Affective commitment is significantly positively related to intention to remain with the organization.

One of the major reasons older workers give for continuing to work is that they do not have the financial resources to retire (AARP, 2005; Barrington, 2004). Health status also 
significantly affects older workers' decision to continue working in either their career job or a bridge job. Quinn (1999) found that the poorer the health status, the more likely older workers were to leave their career job, the less likely they were to move to a bridge job, and the more likely they were to exit the workforce.

Hypothesis 7: Financial need and health status are significantly positively related to intention to remain with the organization.

\section{Method}

\section{Study Background}

Our study was conducted in conjunction with Canada's Association for the Fifty Plus (CARP). CARP is a national non-profit organization with over 400,000 members that represents the interests of people aged 50 and over in Canada.

\section{Data Collection Procedures}

The two groups of older workers are from a larger research project examining the factors that influence the decision of older workers to remain in, or return to, the workforce. Both web and mail questionnaires were used to collect the data simultaneously in September 2006. On the web questionnaire home page and in the cover letter for the mail questionnaire, a description of the questionnaires was given. Participants were first instructed to read the descriptions for each of the questionnaires and then to complete the questionnaire that best described their current situation. The description for the Sample 1 questionnaire indicated that this questionnaire was designed for those people who remained employed in their career job in an organization. The description for the Sample 2 questionnaire indicated that this questionnaire was to be completed (1) by people who remained in the workforce, i.e., had not officially retired, but who had left 
their career or main job, and (2) by people who had retired but had since returned to the workforce.

\section{Sample 1: Career-job Participants}

The participants in Sample 1 included 395 individuals aged 50 to 70 who remained employed in their career or main job. Their average age was 58 years $(S D=4.33)$. They had been employed in their current organization an average of 15 years $(S D=10.87)$ and in their current job an average of 11 years $(S D=9.07)$. They represented a broad range of industry sectors including healthcare (18\%), government (15\%), education (14\%), services $(10 \%)$, manufacturing (10\%), finance and insurance (7\%), wholesale and retail (7\%), high tech (4\%), and construction (3\%) with $12 \%$ being in various other sectors. They also represented a variety of occupations including professionals (32\%), management (20\%), administrative/secretarial (13\%), technical and support (10\%), sales and customer service (9\%), and skilled trades (6\%) with $10 \%$ in other types of occupations. Sixty-four percent were women and $66 \%$ were married.

\section{Sample 1 Measures}

Unless otherwise noted, the multi-item scales had five-point response categories ranging from 1 (Strongly disagree) to 5 (Strongly agree). The reliability coefficients (Cronbach alpha) for the multi-item scales ranged from .77 to .89 (see Table I).

Work centrality. We assessed work centrality with five items. Four of the items were from the work centrality items identified by Paullay et al., (1994) and one item was adapted from Warr, Cook and Wall (1979). Sample items are "The major satisfaction in my life comes from my work" and "The most important things that happen to me involve my work."

Individual factors. We used a single-item measure to assess employment status (employed full or part time). We assessed financial need with two items. Respondents were 
asked to indicate how important maintaining their present standard of living and improving their financial position were in influencing their own decision to remain in the workforce. The response categories ranged from 1 (Not at all important) to 5 (Extremely important).

Organizational factors. We used single-item measures to assess sector (employed in private or public sector) and union status (represented by a labour union or professional association).

Development orientation. Propensity to engage in development activities was measured with five items adapted from the Employability Orientation scale developed by van Dam (2004). Sample items are "I find it important to regularly participate in development activities," and "If the organization offered me a possibility to obtain new work experiences, I would take it."

Job development climate. The 5-item Job Support subscale from the General Training Climate Scale (Tracey \& Tews, 2005) was used to assess job development climate. Sample items are "My job assignments are designed to promote personal development" and "My work assignments include opportunities to learn new techniques and procedures for improving my performance."

Affective commitment. Affective commitment was measured with three items from the Meyer, Allen and Smith (1993) Affective Commitment scale. A sample item is "I feel a strong sense of 'belonging' to this organization."

Intention to remain. Intention to remain with the organization was assessed with three items adapted from various measures. The items are: "Barring unforeseen circumstances, I would remain in this organization indefinitely," "If I were completely free to choose, I would prefer to continue working in this organization," and "I expect to continue working as long as possible in this organization." 
Health status. Current health status was measured with five items four of which were adapted from Adams (1999) and one was from Taylor and Shore (1995). A sample item is "Overall, I am very satisfied with my health."

Demographic variables. The demographic variables included specific industry in which currently employed, length of time employed in the organization, occupational category, length of time in current job position, and marital status.

\section{Sample 2: Bridge-job Participants}

The participants in Sample 2 included 195 people aged 50 to 70 who considered themselves to be employed in a bridge job. Their average age was 61 years $(S D=4.50)$. They had been employed with their current organization an average of 9 years $(S D=11.47)$ and in their current job an average of 4 years $(S D=3.49)$. They also represented a wide range of industry sectors including services (17\%), education (15\%), wholesale and retail (14\%), healthcare (9\%), government (7\%), manufacturing (5\%), finance and insurance (4\%), and construction (2\%) with $27 \%$ being in other sectors. They were in a variety of occupations including professional (24\%), sales and customer service (20\%), administrative/secretarial (13\%), management (12\%), technical and support (10\%), and skilled trades (6\%) with $15 \%$ in other types of occupations. There were 98 men and 95 women ( 2 missing values) and the majority $(73 \%)$ was married.

\section{Sample 2 Measures}

The measures of employment status, sector, union status, development orientation, job development climate, affective commitment, and intention to remain in the organization were the same as those used in Sample 1. The reliability coefficients (Cronbach alpha) for the multi-item scales ranged from .76 to .88 (see Table II). 
Individual factors. To measure financial need to work, respondents were asked to indicate how important various reasons were in influencing their own decision to take a bridge job. Four of these items referred to financial reasons including "Could not afford to retire completely" and "Maintain employer-provided benefits." The response categories ranged from 1 (Not at all important) to 5 (Extremely important). We assessed bridge job entry with a single item: "Did you go directly from your career or main job to your bridge job?" The responses were: Yes or No, spent some time out of the workforce.

Perceived overqualification. We assessed the extent to which respondents felt their bridge job underutilized their skills with six items adapted from the Scale of Perceived Overqualification (SPOQ) developed by Maynard, Joseph and Maynard (2006). A sample item is "My previous training is not being fully utilized on my bridge job."

Demographic variables. In addition to industry in which currently employed, length of time employed in the organization, occupational category, length of time in current bridge job, and marital status, we collected more specific information about a respondent's bridge job. This included whether their bridge job was in the same/different organization, in the same/different industry, and in the same/different occupation as their career job.

\section{Data Analysis}

Path analysis, using LISREL 8.54 (Jöreskog \& Sörbom, 2003), was conducted to test the hypothesized model separately for the two samples. The analysis was based on the covariance matrix and used maximum likelihood estimation. We evaluated the significance of the hypothesized paths and assessed the overall fit of the model to the data with several fit indices including the LISREL goodness-of-fit index (GFI), the adjusted goodness-of-fit index (AGFI), the root-mean-square error of approximation (RMSEA), the non-normed fit index (NNFI), and 
the comparative fit index (CFI). We also compared the fit of the hypothesized model with the fit of alternative nested models.

Results

Over two-thirds (67\%) of respondents in bridge jobs indicated that their bridge job was in a different occupation than their career job, $64 \%$ indicated that their bridge job was in a different industry than their career job, and $83 \%$ indicated that their bridge job was in a different organization than their career job. Close to $44 \%$ indicated they had gone directly from their career or main job to a bridge job whereas $56 \%$ indicated they had spent some time out of the workforce prior to taking a bridge job.

Respondents in career jobs differed from respondents in bridge jobs on several demographic and work-related characteristics. Respondents who remained in their career job were significantly younger $\left(t_{(588)}=7.68, p<.001\right)$ and had significantly more organizational tenure $\left(t_{(577)}=-6.27, p<.001\right)$ and job tenure $\left(\left(t_{(573)}=-9.85, p<.001\right)\right.$ than respondents in bridge jobs. Approximately $85 \%$ of career-job respondents were working full time whereas $67 \%$ of bridge-job respondents were working part time. Just over half of career-job respondents indicated they were represented by a labour union or professional association compared with $29 \%$ of those in bridge jobs. Compared with career-job respondents, bridge-job respondents were more likely to be employed in the private sector and more specifically in the services and wholesale and retail sectors and in smaller organizations (less than 100 employees).

We conducted confirmatory factor analysis to establish the distinctiveness of the five central measures (work centrality, development orientation, job development climate, affective commitment, and intention to remain). For both samples, the results showed that the 5-factor model fit the data significantly better than when factors were equated. For the career-job sample, 
the fit indices for the 5-factor model were: $\chi^{2}=392.44, \mathrm{GFI}=.91, \mathrm{AGFI}=.88, \mathrm{NNFI}=.97, \mathrm{CFI}$ $=.97$, and RMSEA $=.058$. For the bridge-job sample, the fit indices for the 5 -factor model were: $\chi^{2}=273.23, \mathrm{GFI}=.88, \mathrm{AGFI}=.83, \mathrm{NNFI}=.96, \mathrm{CFI}=.97$, and $\mathrm{RMSEA}=.056$.

The means, standard deviations and correlations are presented in Table I for career-job respondents and in Table II for bridge-job respondents. There were no significant differences between the two groups for work centrality $\left(t_{(585)}=.10, p>.05\right)$, health status $\left(t_{(578)}=1.67, p>\right.$ $.05)$, affective commitment $\left(t_{(585)}=-.66, p>.05\right)$, and intention to remain with their organization $\left(t_{(585)}=1.38, p>.05\right)$, but there was a significant difference for development orientation $\left(t_{(580)}=\right.$ $-4.68, p<.001)$ and a marginally significant difference for job development climate $\left(t_{(577)}=\right.$ $-1.90, p=.057)$. Compared with respondents in bridge jobs, respondents in career jobs reported a greater propensity to engage in development activities and were more likely to perceive their job provided them with development opportunities.

take in Tables I and II

\section{Overall Fit of the Hypothesized and Alternative Models}

The fit indices for the hypothesized and alternative models are presented in Table III. A model is considered to have a good fit to the data when the fit indices have a value of .90 or higher and the RMSEA has a value lower than .08 (Kelloway, 1998). For respondents in bridge

take in Table III

jobs, the fit indices for the hypothesized model (Model 1) showed that this model had a relatively good fit to the data. However, this was not true for respondents in career jobs. For this group, 
the AGFI and the NNFI were below .90 and the RMSEA was above .08. Model 2 in which development orientation and job development climate had both direct and indirect effects on intention to remain showed a better fit to the data for career-job respondents than Model 1. For bridge-job respondents, Model 2 showed a similar fit to the data as Model 1 but the direct paths between development orientation and job development climate and intention to remain were not significant. Model 3 in which development orientation was directly related to affective commitment had a significantly poorer fit to the data than the models where development orientation was indirectly related to affective commitment through job development climate. For both groups, Model 4 in which development orientation, job development climate and affective commitment had only direct paths to intention to remain showed the poorest fit to the data.

For career-job respondents, the modification indices indicated that the fit of Model 2 would be improved if a path were added between work status and affective commitment. When this path was included (Model 5cj), all of the fit indices were in the acceptable range indicating that this revised model had a better fit to the data than the other models. For bridge-job respondents, the modification indices indicated that the fit of the hypothesized model (Model 1) would be improved if a path were added between perceived overqualification and affective commitment. When this path was included in Model 5bj, all of the fit indices, including the NNFI, were in the acceptable range. Hypothesized Relationships among Variables

Career-job respondents. The maximum likelihood standardized parameter estimates for the revised model (Model 5cj) for the career-job respondents are shown in Figure 2. All of the hypothesized paths were significant and in the predicted direction. Work centrality was significantly positively related to development orientation, job development climate, affective 
commitment, and intention to remain. Respondents in full-time career jobs were significantly more likely to engage in development activities than respondents in part-time career jobs. Financial need was significantly positively related to development orientation and intention to remain. Career-job respondents employed in the public sector perceived a significantly more supportive job development climate than those in the private sector. Union status was

take in Figure 2

significantly positively related to job development climate indicating that respondents in career jobs who were represented by a labour union or professional association perceived a significantly less supportive job development climate than those who did not have union representation. Health status was significantly positively related to intention to remain indicating that respondents in better health were significantly more likely to remain with their organization than those in poorer health. There were significant positive relationships between development orientation and job development climate, between job development climate and affective commitment, and between affective commitment and intention to remain. Not predicted were the significant positive relationships between development orientation and intention to remain and between job development climate and intention to remain.

Bridge-job respondents. The maximum likelihood standardized parameter estimates for the revised model (Model 5bj) for the bridge-job respondents are shown in Figure 3. A dashed line indicates that the path coefficient was not significant. Work centrality was significantly positively related to development orientation and intention to remain but was not significantly related to job development climate and affective commitment. Respondents in full-time bridge jobs were significantly more likely to engage in development activities than those in part-time 
take in Figure 3

bridge jobs. Financial need was significantly positively related to development orientation but was not significantly related to intention to remain. Respondents who indicated they had spent some time out of the workforce prior to entering their bridge job were significantly more likely to engage in development activities than those who went directly from their career job to their bridge job. Contrary to prediction, sector was not significantly related to job development climate. Respondents who were represented by a labour union or professional association perceived significantly fewer job development opportunities than those who did not have union representation. Perceived overqualification was significantly negatively related to job development climate. Contrary to prediction, health status was not significantly related to intention to remain. There were significant positive relationships between development orientation and job development climate, between job development climate and affective commitment, and between affective commitment and intention to remain.

\section{Discussion}

Older workers who had a greater propensity to engage in development activities perceived that their job provided them with more development opportunities and, in turn, were more committed to their organization and intended to remain with their organization than those who were not inclined to pursue development activities and whose job did not provide them with opportunities for development. This is consistent with Fuller and Unwin (2005) who argued for the need to recognize not only the importance of organizational factors in shaping the character and availability of workplace development opportunities but also that individuals are active agents who determine the extent to which they will engage in the development opportunities 
open to them. Moreover, there was a great deal of similarity in the pattern of these relationships for career-job and bridge-job respondents indicating that development orientation and job development climate play an important role in the retention of older workers in bridge jobs as well as those in career jobs. The findings suggest that to retain older workers employers need to ensure that older workers' jobs promote personal development and that their work assignments include adequate opportunities to learn new knowledge and skills. However, employers need to be aware that not all older workers will take advantage of these development opportunities.

Older workers who view work as a very important aspect of their life, who are in full-time jobs, and who financially need to work are more likely to engage in development activities than those who have low work centrality, who are in part-time jobs, and who are not financially dependent on their job.

At the same time, organizational characteristics are associated with the extent to which employers are providing older workers with development opportunities on their job. Older workers were less likely to have access to development opportunities if they were represented by a labour union or professional association. This is consistent with the speculation in the literature that union rules and policies and a focus on younger members do not lend themselves to promoting job development opportunities for older members. However, the type of job a unionized person holds could be a contributing factor to the lack of development opportunities. For career-job respondents, working in a public sector organization provided greater access to development opportunities. For bridge-job respondents, feeling their bridge job underutilized their knowledge and skills was not only associated with a perceived lack of development opportunities in their job but also with less commitment to their organization. 
Although there were many similarities in the pattern of hypothesized relationships, there were also some differences between career-job and bridge-job respondents. Bridge-job respondents were less likely to engage in development opportunities and more likely to perceive their job as offering fewer development opportunities than career-job respondents. There are a number of possible explanations for this. Bridge-job respondents on average were older than career-job respondents and had already left their long-term career job so there may have been less motivation to engage in development activities. Two-thirds of bridge-job respondents were in part-time jobs and being employed part time was associated with a perceived lack of job development opportunities. Bridge jobs in general have a reputation of being dead-end jobs (Doeringer, 1990) that are unlikely to encourage older workers to engage in development activities or to provide a supportive job development climate.

Both groups reported a similar level of work centrality, but work centrality did not play the same prominent role for bridge-job respondents that it did for career-job respondents. For bridge-job respondents, work centrality was significantly positively related to development orientation and intention to remain but was not significantly related to job development climate and affective commitment. For career-job respondents, work centrality was significantly positively related to all four variables. For career-job respondents, work centrality, financial need to work, development orientation, job development climate, affective commitment, and health status were all significant predictors of intention to remain with the organization. For bridge-job respondents, only work centrality and affective commitment were significant predictors of intention to remain with the organization.

This study extends our existing knowledge of the factors that are important to the development and retention of older workers. There is little empirical research addressing issues 
related to the development of people aged 50 and over. Much of the research that has been conducted has focused on negative age stereotyping and its implications for older workers' access to development opportunities. In addition, no studies were found that have investigated both development orientation and job development climate in the context of older workers. Much of the existing research treats older workers as a homogeneous group. The present study distinguished between older workers who were in career jobs and those who were in bridge jobs. There has been little empirical research on bridge employment yet this form of employment is expected to become much more prevalent among older workers in the future (Adams \& Rau, 2004). Research that provides greater insight into bridge employment and the older workers who participate in this type of employment is clearly needed. Given the expected dependence of employers on older bridge workers in the future, it is important to explore management's approach to this group of older workers as well as to heighten management's awareness of how to effectively recruit and retain older bridge workers.

The present study represents an initial step in exploring the role of development orientation and development climate in promoting the retention of older workers. Clearly, much more research is warranted in this area. Future research is needed to identify how organizations may strengthen the development orientation of older workers and other organizational characteristics that foster a supportive job development climate. Personality variables, such as openness to new learning experiences, may shape development orientation. Maurer (2002) proposed that the extent that supervisors and coworkers emphasize and support learning and development in employees' daily activities influences their development orientation. There is some empirical evidence that perceived support for development from managers and coworkers influences employees' participation in development activities (Maurer \& Tarulli, 1994; Noe \& 
Wilk, 1993). Moreover, Maurer and Tarulli (1994) found that older employees valued support of development from supervisors and coworkers more than younger employees. Development orientation may also be influenced by a person's self-efficacy for learning and development (Maurer, Wrenn, Pierce, Tross \& Collins, 2003). Potential organizational characteristics that may influence job development climate are age composition of the organization's workforce and job type. Much of the research focus has been on older workers' access to formal training and development programs. Older workers are less likely to have access to formal training and development programs than younger workers and to participate less in these types of programs (Betcherman, McMullen \& Davidman, 1998; Warr \& Birdi, 1998). We suggest that providing older workers with informal development opportunities through their job is a better way to prevent skill obsolescence among older workers.

There are several limitations associated with the present study. We used the age of 50 and over to identify a person as an older worker. There are a number of approaches that can be used to define an older worker (see Sterns \& Miklos, 1995) and chronological age, although convenient, may not be the most appropriate approach to use. The research design was crosssectional and the data were collected from a single source using a single method. It is therefore not possible to establish the causal nature of the relationships among development orientation, development climate, affective commitment and intention to remain. These relationships may be inflated because of common method variance. To address the issue of common method bias, we conducted confirmatory factor analysis to establish the distinctiveness of the key variables in the conceptual model. It is possible that development opportunities and actual engagement in development activities would, in turn, influence development orientation. Researchers would need to use a longitudinal research design to examine the causal nature of these relationships or 
to conduct a field experiment in which some organizations would implement a program designed to provide older employees' with greater job development opportunities. The development orientation of these older employees could then be compared with the development orientation of older employees in other organizations serving as a control group that did not implement such a program. The measures of development orientation and development climate used in the present study were developed fairly recently and have not undergone extensive research to establish their psychometric properties.

As the workforce continues to age and labour and skill shortages become a major concern, the challenge for employers will be to convince older workers to remain in, or return to, the labour force. This will require making the workplace more attractive and appealing so that older workers will want to continue working. Learning and development will play a crucial role in making the workplace appealing to older workers and at the same time making older workers attractive to employers. Taking steps to strengthen older workers' development orientation and providing older workers with a supportive development climate are important in fostering older workers' commitment and intention to remain. 


\section{References}

AARP (2005) "Attitudes of individuals 50 and older toward phased retirement", American Association for Retired Persons, Washington, DC.

Adams, G.A. (1999) “Career-related variables and planned retirement age: An extension of Beehr's model”, Journal of Vocational Behavior, Vol. 55 No. 2, 221-235.

Adams, G., and Rau, B. (2004) “Job seeking among retirees seeking bridge employment”, Personnel Psychology, Vol. 57 No. 3, 719-749.

Allen, D.G., Shore, L.M. and Griffeth, R.W. (2003) “The role of perceived organizational support and supportive human resource practices in the turnover process", Journal of Management, Vol. 29 No. 1, 99-118.

Auer, P. and Fortuny, M. (2000), Ageing of the Labour Force in OECD Countries: Economic and Social Consequences, International Labour Office: Geneva.

Barrington, L. (2004), Demographic Trends and the Older Workforce, The Conference Board, New York.

Betcherman, G., McMullen, K. and Davidman, K. (1998), Training for the New Economy, Canadian Policy Research Networks, Inc., Ottawa.

Blau, P.M. (1964), Exchange and Power in Social Life, Wiley: New York.

The Conference Board of Canada (2005), Work-to-retirement Transition: An Emerging Business Challenge, The Conference Board of Canada, Ottawa.

Doeringer, P.B. (1990), Bridges to Retirement: Older Workers in a Changing Labor Market. ILR Press: Ithaca, NY. 
Feldman, D.C. and Kim, S. (2000) "Bridge employment during retirement: A field study of individual and organizational experiences with post-retirement employment", Human Resource Planning, Vol. 23 No. 1, 14-25.

Forum of Labour Market Ministers (2002) "Older workers in the labour market: Employment challenges, programs and policy implications", retrieved from http://www.hrdcdrhc.gc.ca/stratepol/lmp/owe_toc.shtml

Fugate, M., Kinicki, A.J. and Ashforth, B.E. (2004) "Employability: A psycho-social construct, its dimensions, and applications", Journal of Vocational Behavior, Vol. 65 No.1,14-38.

Fuller, A. and Unwin, L. (2005) “Older and wiser?: workplace learning from the perspective of experienced employees”, International Journal of Lifelong Education, Vol. 24 No. 1, 2139.

Gouldner, A.W. (1960), “The norm of reciprocity: A preliminary statement”, American Sociological Review, Vol. 25, No. 2, 161-178.

Greller, M.M. (2006) "Hours invested in professional development during late career as a function of career motivation and satisfaction”, Career Development International, Vol. 11 No. 6, 544-559.

Ibbott, P., Kerr, D. and Beaujot, R. (2006) "Probing the future of mandatory retirement in Canada”, Canadian Journal of Aging, Vol. 25 No. 2, 161-178.

Jöreskog, K.\& Sörbom, D. (2003), LISREL® 8.54, Scientific Software International, Chicago. Kelloway, E. K. (1998), Using LISREL for Structural Equation Modeling, Sage Publications, Inc., Thousand Oaks.

Kozlowski, S.W.J. and Hults, B.M. (1987) “An exploration of climates for technical updating and performance", Personnel Psychology, Vol. 40 No. 3, 539-563. 
Leavitt, T. (1996) "Labor force characteristics of older Americans", in Crown, W.H. (Ed.), Handbook on Employment and the Elderly, Greenwood Press, Westport, CT, pp. 15-56.

Mannheim, B., Baruch, Y. and Tal, J. (1997) “Alternative models for antecedents and outcomes of work centrality and job satisfaction of high-tech personnel”, Human Relations, Vol. 50 No. $12,1537-1562$.

Mannheim, B. and Dubin, R. (1986) "work role centrality of industrial workers as related to organizational conditions, task autonomy, managerial orientations and personal characteristics", Journal of Occupational Behavior, Vol. 7 No. 2, 107-124.

Maurer, T.J. (2001) "Career-relevant learning and development, worker age, and beliefs about self-efficacy for development", Journal of Management, Vol. 27 No. 2, 123-140.

Maurer, T.J. (2002) "Employee learning and development orientation: Toward an integrative model of involvement in continuous learning", Human Resource Development Review, Vol. 1 No. 1, 9-44.

Maurer, T.J. and Tarulli, B.A. (1994) "Investigation of perceived environment, perceived outcome, and person variables in relationship to voluntary development activity by employees", Journal of Applied Psychology, Vol. 79 No. 1, 3-14.

Maurer, T.J., Wrenn, K.A., Pierce, H.R., Tross, S.A. and Collins, W.C. (2003) "Beliefs about ‘improvability’ of career-relevant skills: relevance to job/task analysis, competency modeling, and learning orientation”, Journal of Organizational Behavior, Vol. 24 No. 1, $107-131$.

Maynard, D.C., Joseph, T.A., and Maynard, A.M. (2006) “Underemployment, job attitudes, and turnover intentions', Journal of Organizational Behavior, Vol. 27 No. 4, 509-536. 
McNair, S., Flynn, M., Owen, L., Humphreys, C. and Woodfield, S. (2004) "Changing work in later life: A study of job transitions", available at http://www.surrey.ac.uk/crow/CROWreport-1.pdf.

Meyer, J.P. (1997). “Organizational commitment”, in Cooper, C.L. and Robertson, I.T. (Eds.), International Review of Industrial and Organizational Psychology, Vol. 12, John Wiley \& Sons Ltd., New York, pp. 175-228.

Meyer, J.P., Allen, J.J. and Smith, C.A. (1993) “Commitment to organizations and occupations: Extension and test of a three-component conceptualization”, Journal of Applied Psychology, Vol. 78 No. 4, 538-551.

Meyer, J.P. and Smith, C.A. (2000) "HRM practices and organizational commitment: Test of a mediation model", Canadian Journal of Administrative Sciences, Vol. 17 No. 4, 319-331.

Noe, R.A. and Wilk, S.L. (1993) 'Investigation of the factors that influence employees' participation in development activities”, Journal of Applied Psychology, Vol. 78 No. 2, 291-302.

O'Reilly, P. and Caro, F. (1994) "Productive aging: An overview of the literature", Journal of Aging and Social Policy, Vol. 6 No. 3, 37-71.

Paullay, I.M., Alliger, G.M. and Stone-Romero, E.F. (1994) "Construct validation of two instruments designed to measure job involvement and work centrality", Journal of Applied Psychology, Vol. 79 No. 2, 224-228.

Quinn, J.F. (1999) Retirement Patterns and Bridge Jobs in the 1990s, EBRI Issue Brief Number 206, Employee Benefit Research Institute, Washington, DC.

Ruhm, C. (1990) "Bridge jobs and partial retirement”, Journal of Labor Economics, Vol. 8 No. 4, 482-501. 
Seibert, S.E., Crant, J.M. and Kraimer, M.L. (1999) "Proactive personality and career success", Journal of Applied Psychology, Vol. 84 No. 3, 416-427.

Soon, L.G. and Tin, N.L. (1997) "Early retirement and bridge employment intentions among older workers in Singapore”, Asia Pacific Journal of Management, Vol. 14 No. 2, 185 210.

Statistics Canada (2003) “The changing profile of Canada's labour force”, retrieved from http://www.statcan.ca/Daily

Sterns, H.L. and Miklos, S.M. (1995) “The aging worker in a changing environment: Organizational and individual issues", Journal of Vocational Behavior, Vol. 47 No. 3, 248-268.

Taylor, M.A. and Shore, L.M. (1995) "Predictors of planned retirement age: An application of Beehr's model", Psychology and Aging, Vol. 10 No. 1, 76-83.

Taylor, P. and Urwin, P. (2001) “Age and participation in vocational education and training", Work, Employment \& Society, Vol.15 No., 763-779.

Tracey, J.B. and Tews, M.J. (2005) “Construct validity of a General Training Climate Scale”, Organizational Research Methods, Vol. 8 No. 4, 353-374.

van Dam, K. (2004) “Antecedents and consequences of employability orientation”, European Journal of Work and Organizational Psychology, Vol. 13 No. 1, 29-51.

Warr, P.B. and Birdi, K. (1998) “Employee age and voluntary development activity”, International Journal of Training and Development, Vol. 2 No. 3, 190-204.

Warr, P.B., Cook, J. and Wall, T.C. (1979) "Scale for the measurement of some work attitudes and aspects of psychological well-being”, Journal of Occupational Psychology, Vol. 52 No. 2, 129-148. 
Table I

Career Job Means, Standard Deviations, and Correlations

\begin{tabular}{|c|c|c|c|c|c|c|c|c|c|c|}
\hline & 1 & 2 & 3 & 4 & 5 & 6 & 7 & 8 & 9 & 10 \\
\hline 1. Financial need & .77 & & & & & & & & & \\
\hline 2. Work status & -.07 & & & & & & & & & \\
\hline 3. Work centrality & .05 & -.00 & .79 & & & & & & & \\
\hline 4. Sector & .08 & .06 & -.12 & & & & & & & \\
\hline 5. Union status & -.03 & -.14 & .15 & -.53 & & & & & & \\
\hline 6. Health status & .02 & .01 & .10 & -.03 & .03 & .89 & & & & \\
\hline 7. Devel orientation & .14 & -.08 & .29 & .01 & .11 & .17 & .82 & & & \\
\hline 8. Job devel climate & .03 & -.02 & .24 & .04 & .13 & .07 & .31 & .82 & & \\
\hline 9. Commitment & .02 & -.08 & .34 & -.03 & .09 & .01 & .18 & .50 & .78 & \\
\hline 10. Intent to remain & .18 & -.02 & .46 & -.08 & .15 & .20 & .33 & .46 & .56 & .82 \\
\hline Mean & 4.30 & --- & 3.09 & --- & --- & 3.76 & 3.95 & 3.31 & 3.03 & 3.12 \\
\hline SD & .79 & --- & .80 & --- & --- & .85 & .69 & .82 & 1.01 & 1.12 \\
\hline
\end{tabular}

Reliability coefficients for the multi-item scales are shown on the diagonal.

Significance levels: $r>.09, p<.05 ; r>.12, p<.01 ; r>.17, p<.001$ 
Table II

Bridge Job Means, Standard Deviations, and Correlations

\begin{tabular}{|c|c|c|c|c|c|c|c|c|c|c|c|c|}
\hline & 1 & 2 & 3 & 4 & 5 & 6 & 7 & 8 & 9 & 10 & 11 & 12 \\
\hline \multicolumn{13}{|l|}{ 1. Bridge job entry } \\
\hline 2. Financial need & .18 & .76 & & & & & & & & & & \\
\hline 3. Work status & -.10 & -.20 & & & & & & & & & & \\
\hline 4. Work centrality & .05 & .24 & -.12 & .79 & & & & & & & & \\
\hline 5. Sector & -.03 & -.11 & .11 & -.02 & & & & & & & & \\
\hline 6. Union status & .18 & .16 & -.03 & .03 & -.49 & & & & & & & \\
\hline 7. Overqualified & .23 & .28 & -.11 & -.00 & -.34 & .31 & .84 & & & & & \\
\hline 8. Health status & -.09 & -.09 & -.02 & .10 & -.09 & .09 & .03 & .88 & & & & \\
\hline 9. Devel orientation & .27 & .33 & -.24 & .42 & -.07 & .07 & .17 & .07 & .78 & & & \\
\hline 10. Job devel climate & .03 & -.01 & -.09 & .17 & .08 & .03 & -.25 & -.02 & .34 & .87 & & \\
\hline 11. Commitment & -.06 & -.14 & .08 & .26 & .15 & -.11 & -.30 & .02 & .17 & .52 & .85 & \\
\hline 12. Intent to remain & -.03 & -.06 & .00 & .40 & .07 & -.05 & -.10 & .11 & .24 & .42 & .57 & .83 \\
\hline Mean & --- & 2.31 & --- & 3.10 & --- & --- & 3.62 & 3.88 & 3.66 & 3.17 & 2.97 & 3.25 \\
\hline SD & --- & 1.08 & --- & .78 & --- & --- & .85 & .73 & .72 & .78 & .92 & .92 \\
\hline
\end{tabular}

Reliability coefficients for the multi-item scales are shown on the diagonal.

Significance levels: $r>.13, p<.05 ; r>.18, p<.01 ; r>.24, p<.001$ 
Table III

Fit Indices for the Hypothesized Model and Alternative Models

$\begin{array}{lllllll}\mathrm{X}^{2} & \mathrm{df} & \text { GFI } & \text { AGFI } & \text { NNFI } & \text { CFI } & \text { RMSEA }\end{array}$

\section{Career Job}

Model 1 Hypothesized model

$\begin{array}{lllllll}83.59 & 17 & .96 & .86 & .81 & .93 & .103\end{array}$

Model 2a

$\begin{array}{lllllll}54.75 & 15 & .97 & .90 & .87 & .96 & .085\end{array}$

Model $3^{\text {b }}$

$\begin{array}{lllllll}104.18 & 17 & .95 & .83 & .76 & .91 & .118\end{array}$

Model $4^{\mathrm{c}}$

$\begin{array}{lllllll}141.43 & 12 & .93 & .68 & .41 & .84 & .172\end{array}$

Model $5 \mathrm{cj}^{\mathrm{d}}$ Revised model

$\begin{array}{lllllll}41.85 & 14 & .98 & .91 & .90 & .97 & .074\end{array}$

\section{Bridge Job}

Model 1 Hypothesized model

$\begin{array}{lllllll}41.19 & 24 & .96 & .87 & .91 & .97 & .068\end{array}$

Model 2a

$\begin{array}{lllllll}37.49 & 22 & .96 & .87 & .90 & .97 & .067\end{array}$

Model $3^{\mathrm{b}}$

$\begin{array}{lllllll}61.64 & 23 & .94 & .80 & .78 & .92 & .104\end{array}$

Model $4^{\mathrm{c}}$

83.25

17

Model 5bj ${ }^{\mathrm{e}}$ Revised model

$31.31 \quad 23$

17

.92

.84

$.53 \quad .88$

.159

Model sbje Revised model

${ }^{a}$ Model 2 has additional paths from development orientation and job development climate to intention to remain.

${ }^{\mathrm{b}}$ Model 3 has direct paths between development orientation and job development climate and affective commitment but no path between development orientation and job development climate.

${ }^{\mathrm{c}}$ Model 4 has only direct paths between development orientation, job development climate, and affective commitment and intention to remain.

${ }^{\mathrm{d}}$ Model $5 \mathrm{cj}$ for career-job respondents has a path added in Model 2 between work status and affective commitment.

${ }^{\mathrm{e}}$ Model 5bj for bridge-job respondents has a path added in Model 1 between perceived overqualification and affective commitment. 
Figure 1

Conceptual Model

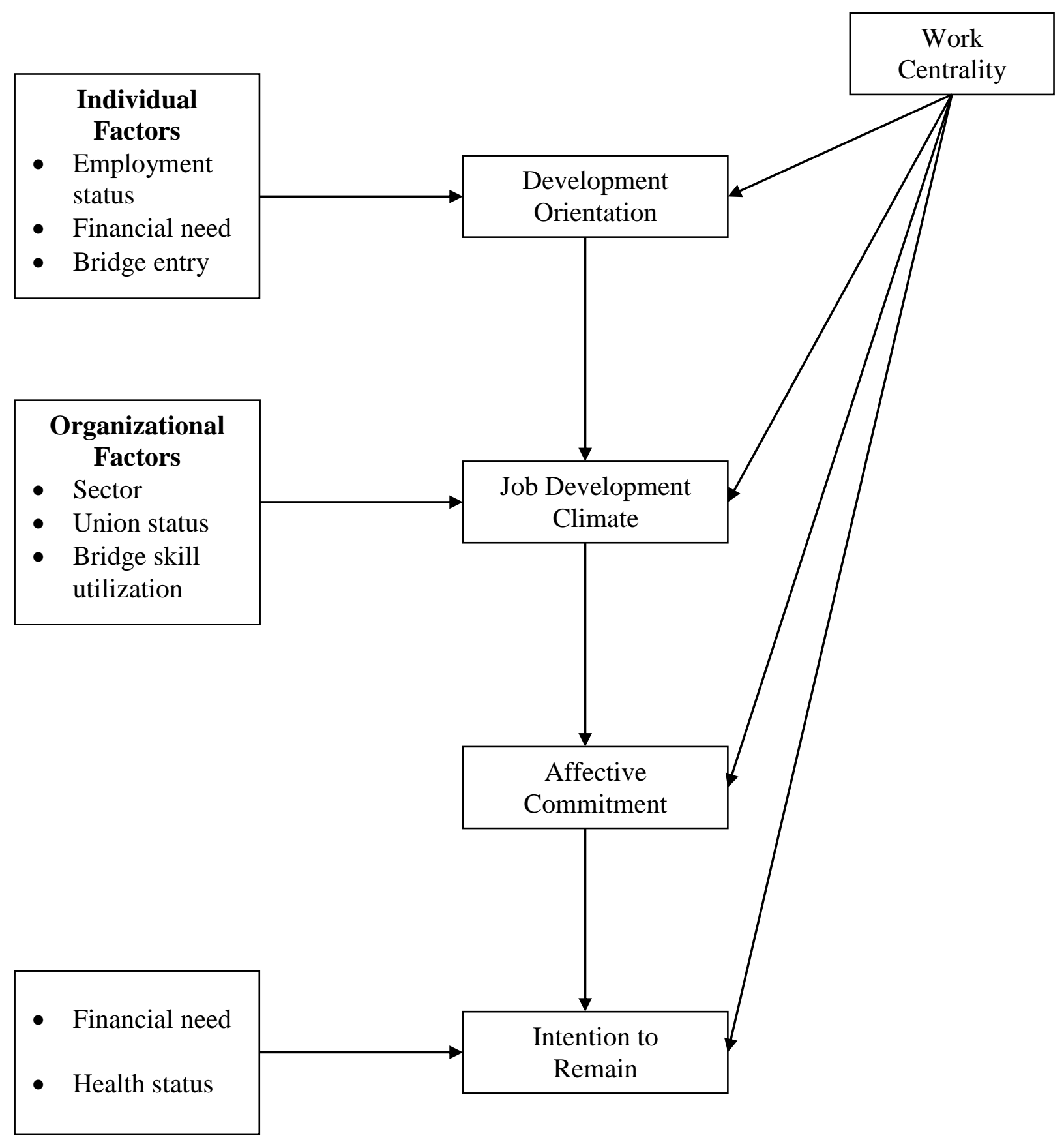


Figure 2

Career-job Sample: Standardized Parameter Estimates for the Revised Model

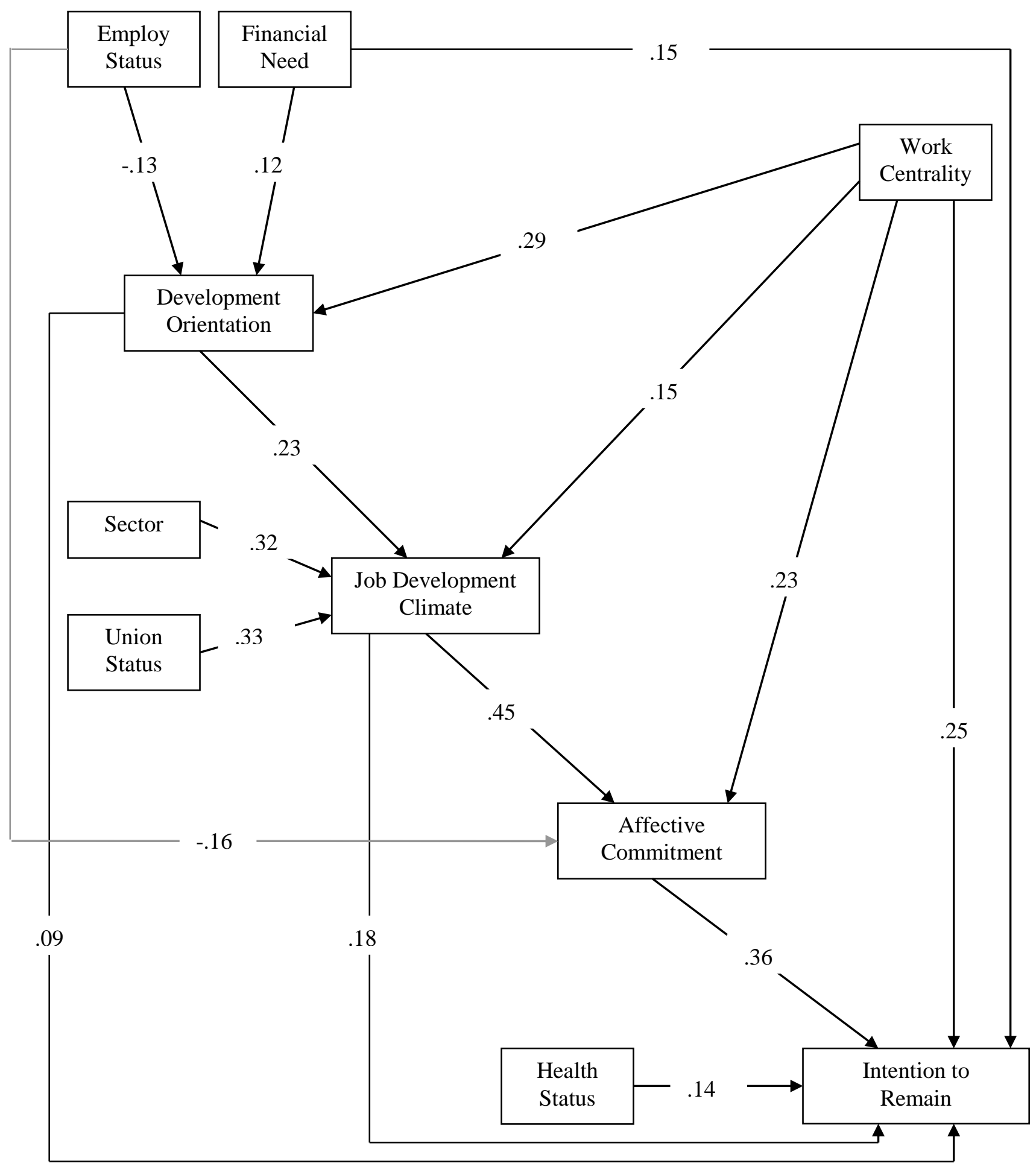


Figure 3

Bridge-job Sample: Standardized Parameter Estimates for the Revised Model

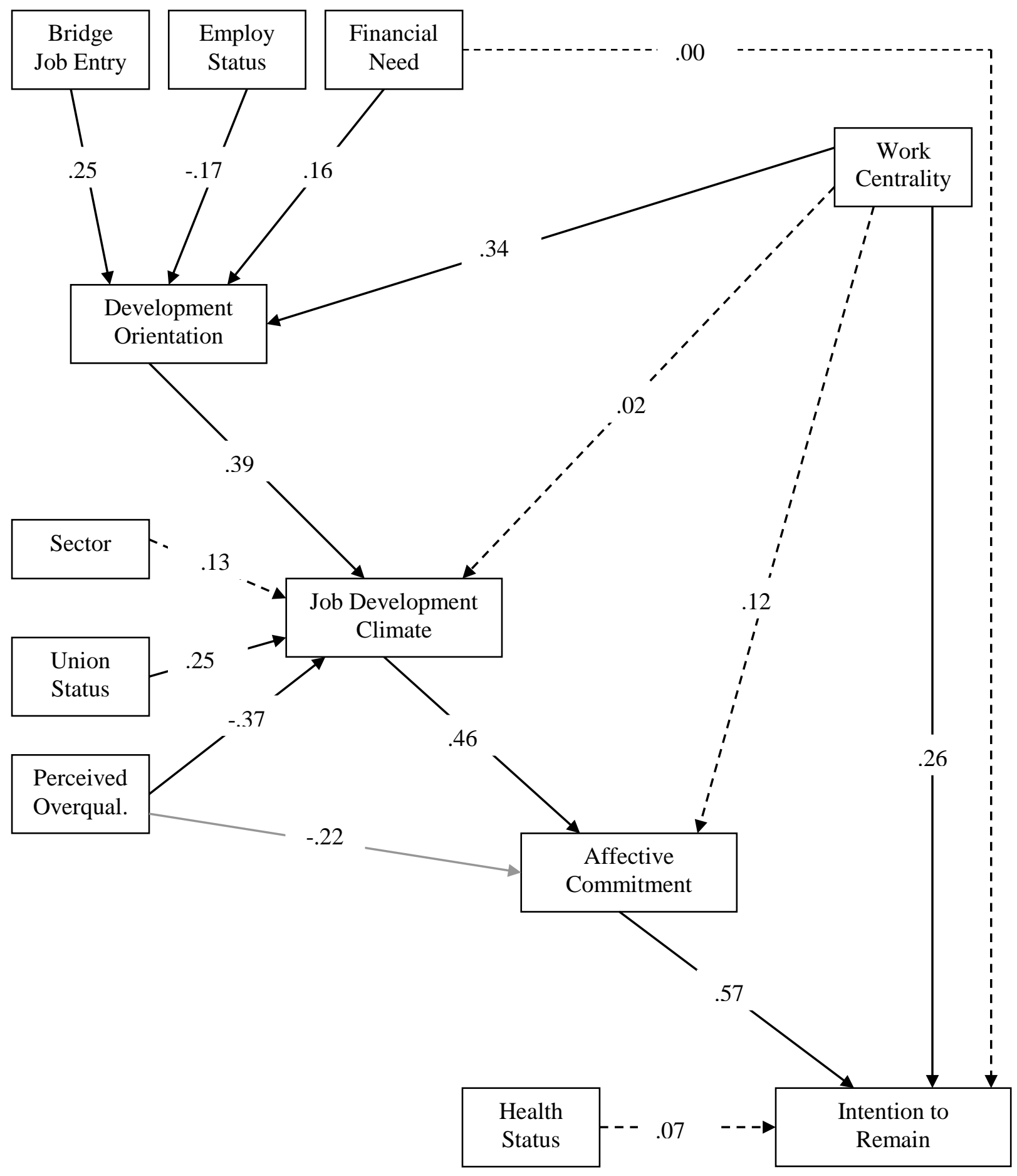

